\title{
Secular Change in Body Size and Somatotype of Indonesian Children aged 7-15 Years (1999-2019)
}

\author{
Neni Trilusiana Rahmawati ${ }^{1,2 *}$ (D), Janatin Hastuti ${ }^{1,2}$ (D) \\ ${ }^{1}$ Lab. of Bioanthropology, Faculty of Medicine, Public Health and Nursing, Universitas Gadjah Mada, Yogyakarta, Indonesia; \\ ${ }^{2}$ Department of Health Nutrition, Faculty of Medicine, Public Health and Nursing, Universitas Gadjah Mada, Yogyakarta, \\ Indonesia
}

Edited by: Slavica Hristomanova-Mitkovska Citation: Rahmawati NT, Hastuti J. Secular Change Body Size and Somatotype of Indonesian Children age 7-15 Years (1999-2019). Open Access Maced J Med Sci. https://doi $2021 \mathrm{May} 13,9(\mathrm{E}): 419-427$ Keywords: Secular change; Body size; Body mass index; *Correspondence: Neni Trilusiana Rahmawati, Lab. of Bioanthropology, Faculty of Medicine, Public Health an Nursing, Universitas Gadjah Mada, Sekip Yogyakarta 55281, Indonesia. E-mail: neni.rahmawati@ugm.ac.iı Received: 07-Apr-202 Revised: 02-May-202 Accepted: 03-May-202
Copyright: $\odot 2021$ Neni Trilusiana Rahmawati Janatin Hastuti Funding: This study was supported by the Faculty Medicine, Public Health and Nursing, Universitas Gadja Mada, Yogyakarta, Indonesia
competing Interests: The authors have declared that no
competing interests exis
Open Access: This is an open-access article distributed Mada, Yogyakarta, Indonesia
competing Interests: The authors have declared that no
competing interests exis
Open Access: This is an open-access article distributed Open Access: This is an open-access article distribute NonCommercial 4.0 International License (CC BY-NC 4.0)

\section{Introduction}

Assessment of secular changes during growth periods can help identifying the quality of health, wealth, and nutrition among populations [1] and provide suggestions for public health policymakers to identify strategies for further improvements in child health [2], [3], [4], [5]. Many studies in secular trends of obesity were conducted over the last few decades. The results varied in different populations and regions, for example, the prevalence of obesity continuously increased in Chinese boys and girls over 25 years period (19852010), with boys changing faster than girls [6]. The increased obesity also has been reported in Sicilian school children between 1999 and 2010, showing that the trend was related to age, gender, and regions [7]. The increase prevalence of obesity is often associated with a reduction in malnourished children [7], [8]. As the risk of childhood obesity increases, its health implications (e.g., dyslipidemia and hypertension), which are important risk factors for morbidity and mortality in adults, also become more common in children [9]. In addition, being overweight in children is predictive of overweight adults, which further underscores the importance of studies on obesity in children.

The secular trend of rising obesity is suggested due to a disharmonic secular change in height and weight that leads to higher body mass index (BMI) as found in Argentinian [5] and Polish children [10]. Nonetheless, disparity in growth of height and weight as the components of BMI is associated with obesity in a complex way and may vary between ages, periods, and ethnicities [2], [3], [4], [11]. Conde et al. [3] reported that among Brazilian adolescents over four decades, the BMI and height have increased at different rates in different ways. In addition, the altering increased rate of height has played a protective role against overweight status in adolescents [3]. Meanwhile, among Chinese children, the increased prevalence of obesity may be related to a rapid increase in body weight, especially before age 9 years and lack of secular increase in body height during middle and late puberty development after age 12 years [2], [11]. Papadimitriou et al. [2] suggested that childhood overweight status does not affect adult height, neither positively nor negatively.

Along with the secular changes of body height, weight, and BMI in obesity trends among children, 
changes in certain aspects of body composition, especially somatotype is often undervalued [12]. Somatotype is a quantitative description of shape and composition of the human body. It is expressed with three numerical values corresponding to three physical components, that is, endomorphic, mesomorphic, and ectomorphic components which provide information on relative fatness, musculoskeletal, and linearity, respectively [13]. These three components, therefore, provide the morphological characteristics of individuals as a whole. Somatotype is a good tool to evaluate the biotype of growing and developing children. There is substantial growth of the adipose component in boys and girls which increases the risk of suffering noncommunicable diseases [14].

Evidence supports that somatotype changes have increased, primarily in terms of relative adiposity (i.e., the endomorphic component) and predominantly in adolescent girls in Chile [15]. Further, somatotype trajectory describes a consistency of the mesomorphic endomorph profile in females with an increase in endomorphy, whereas in males, a change was observed from an ectomorphic mesomorph to endomorphic mesomorph [14]. Studies on somatotype in Indonesian children are very few and no studies have reported the secular trend of somatotype. Rahmawati et al. [16] found that children aged 7-12 years in urban and rural areas, before puberty, had a somatotype distribution between endomorphic and mesomorphic. However, children in rural areas tended to be more ectomorphic, while those in urban areas were more endomorphic.

Despite the abundance of studies on secular trends in weight, height, and BMI in many populations worldwide, studies in Indonesian children are very limited, particularly studies on somatotype changes. Accordingly, this study aimed to examine the secular changes in growth of height, weight, BMI, and somatotype in Indonesian children in periods between 1999 and 2019.

\section{Materials and Methods}

\section{Study design and subjects}

This study was descriptive-analytical research with a cross-sectional design on Yogyakarta children (988 boys, 1033 girls) aged 7-15 years living in Yogyakarta Province, Indonesia. Data were collected in two periods, that is, 1157 children (552 boys, 605 girls) in 1999 and 864 children (436 boys, 428 girls) in 2019, which were collected since 2017 . This study was approved by the Medical and Health Research Ethics Committee of Faculty of Medicine, Public Health, and Nursing Universitas Gadjah Mada. Written consent was obtained from the parents of each child.

\section{Measurements}

All children were measured their weight, height, humerus and femur breadths, circumferences of upper arm and calf, and skinfold thickness at triceps, subscapular, suprailiac, and calf following the protocols of the International Society for the Advancement of Kinanthropometry (2006) [17]. Weight was measured with a Seca weight scale (Seca 803, Seca Deutschland) to the nearest $0.1 \mathrm{~kg}$ while subjects were wearing light clothing. Height was measured using an anthropometric set (GPM, Swiss) to the nearest $0.1 \mathrm{~cm}$. BMI was defined as weight/ height $^{2}\left(\mathrm{~kg} / \mathrm{m}^{2}\right)$. Humerus and femur breadths were taken using a small sliding caliper (GPM, Swiss) to the nearest $0.1 \mathrm{~cm}$. Circumferences of upper arm and calf were measured with a non-flexible meter tape (Holtain Ltd., UK) A Harpenden skinfold caliper was used to measure skinfold thickness to the nearest $0.2 \mathrm{~mm}$ at triceps, subscapular, suprailiac, and calf. The somatotype components of participants were calculated according to the Carter-Heath method (1990), using the following equations [13]:

1 .

$$
\begin{aligned}
& \text { Endomorphy }=-0.7182+0.1415(X)-0.00068 \\
& (X 2)+0.0000014\left(X^{3}\right),
\end{aligned}
$$

where $X=$ triceps skinfold $((\mathrm{mm})+\mathrm{mm})+$ subscapular skinfold supraspinal skinfold $(\mathrm{mm}) \times 170.18 /$ height $(\mathrm{cm})$.

2. Mesomorphy $=[(0.858 \times$ humerus breadth $(\mathrm{cm}))+(0.601 \times$ femur breadth $(\mathrm{cm}))+(0.188$ $\times$ corrected arm circumference $(\mathrm{cm}))+(0.161$ $\times$ corrected calf circumference $(\mathrm{cm})]-$ (stature $\times 0.131)+4.5$,

where corrected arm circumference (upper arm circumference $(\mathrm{cm})$ - triceps skinfold $(\mathrm{cm})$ ), and corrected calf circumference (calf girth $(\mathrm{cm})$ - calf skinfold $(\mathrm{cm}))$.

3. Ectomorphy $=0.732 \times \mathrm{HWR}-28.58$; HWR is height/cube root of weight

If HWR is $<40.75$ but more than 38.25 , then Ectomorphy $=0.463 \times$ HWR -17.63 ;

If HWR is equal to or $<38.25$, then Ectomorphy $=0.1$.

Rating on each component of $1 / 2$ to $2 \frac{1}{2}$ are considered low, 3 to 5 are moderate, $5 \frac{1}{2}$ to 7 are high, and $7 \frac{1}{2}$ and above are very high [13].

\section{Statistical analysis}

Analysis of three-way ANOVA and least significant difference post hoc tests were performed to compare the variation between groups. Mean differences between age groups, stratified by gender and periods, were assessed using one-way ANOVA. Statistical analyses were performed using SPSS 25.0 (SPSS Inc, Chicago, IL). The significance level was set at $p<0.05$. 


\section{Results}

Tables 1 and 2 provide mean values and standard deviation (SD) of height, weight, BMI, and somatotype components of children aged 7-12 years from 1999 to 2019. Figures 1-3 show the comparison between components of the somatotype between the two periods.

Table 1 shows the mean of height growth of children aged 7-15 years in 1999 and 2019. There were no significant differences in height among boys between 1999 and 2019; however, positive trends $(p<0.05)$ were observed in girls at the ages of 10 years $(3.6 \mathrm{~cm}), 12$ years $(2.9 \mathrm{~cm}), 14$ years $(2.9 \mathrm{~cm})$, and 15 years $(3.9 \mathrm{~cm})$. In 1999 , the average height of boys was $118.7-159 \mathrm{~cm}$ and in 2019, it was 118.4-163 cm, while in girls, it was 117.0 $151.2 \mathrm{~cm}$ (1999) and $116.1-154.9 \mathrm{~cm}$ (2019). The means of height in boys were greater than girls, but significant differences $(p<0.01)$ between boys and girls were found only at ages 14 and 15 years in 1999 and ages 7,12 , and 15 years in 2019 (Table 1). Results point to a height gain over the 20 years period, especially in girls with a mean increase of $3.3 \mathrm{~cm}$ starting at 10 years of age.
Body weight of boys and girls, in general, showed a significant increase between 1999 and 2019 (Table 1). In boys, significant weight gain $(p<0.01)$ existed at ages 9 and 13 years with 3.7 and $7.1 \mathrm{~kg}$ increments, respectively. In girls, significant weight increased began at 9 years $(2.3 \mathrm{~kg})$ until 15 years $(5.4 \mathrm{~kg})$ except 11 and 13 years. Whereas, differences in body weight between sexes were significant $(p<0.01)$ only at ages 13-14 years in 1999 and 12 years in 2019. The variation in mean weight values between boys and girls over the 20-year interval was similar to that reported for height.

Table 1 also illustrates the BMI of children aged 7-15 years in 1999 and 2019. BMI showed a significant increase $(p<0.01)$ starting at age 9 years in boys with an average gain of $1.8 \mathrm{~kg} / \mathrm{m}^{2}$ and at age 8 years in girls with an average of $1.9 \mathrm{~kg} / \mathrm{m}^{2}$ increment. Further analyses showed that girls were significantly had greater BMI than boys ( $p<0.01$ ) at ages 13 and 15 years (1999) and at ages 12 and 15 years (2019). It should be emphasized that the tendency for an increase in BMI may also be influenced by an increase in body height. The trend line based on the mean values from the 20 years interval was positive for both boys and girls.

Table 1: Comparative differences in height, weight, and BMI between 1999 and 2019 of Yogyakarta children

\begin{tabular}{|c|c|c|c|c|c|c|c|c|}
\hline \multirow[t]{2}{*}{ Age } & \multicolumn{4}{|c|}{1999} & \multicolumn{4}{|c|}{2019} \\
\hline & $\mathrm{n}$ & Height $(\mathrm{cm})$ & Weight (kg) & BMI (kg/m2) & $\mathrm{n}$ & Height $(\mathrm{cm})$ & Weight (kg) & $\mathrm{BMI}(\mathrm{kg} / \mathrm{m} 2)$ \\
\hline \multicolumn{9}{|l|}{ Boys } \\
\hline 7 & 58 & $118.7 \pm 5.7$ & $21.1 \pm 4.0$ & $14.9 \pm 2.1$ & 69 & $118.4 \pm 5.4^{d}$ & $22.2 \pm 6.0$ & $15.7 \pm 3.0$ \\
\hline 8 & 47 & $121.6 \pm 5.7$ & $22.2 \pm 6.2$ & $14.8 \pm 2.8$ & 58 & $121.1 \pm 5.2$ & $23.2 \pm 4.9$ & $15.7 \pm 2.3$ \\
\hline 9 & 55 & $127.2 \pm 5.1$ & $25.0 \pm 4.8^{b}$ & $15.4 \pm 2.1^{b}$ & 72 & $128.2 \pm 8.3$ & $28.7 \pm 9.3$ & $17.2 \pm 3.8$ \\
\hline 10 & 57 & $132.9 \pm 6.8$ & $28.7 \pm 6.5$ & $16.1 \pm 2.5^{b}$ & 50 & $131.2 \pm 6.3$ & $31.4 \pm 10.6$ & $17.9 \pm 4.3$ \\
\hline 11 & 57 & $136.7 \pm 9.6$ & $31.3 \pm 9.5$ & $16.4 \pm 2.8^{\mathrm{a}}$ & 69 & $136.0 \pm 7.4$ & $33.4 \pm 9.8$ & $17.8 \pm 3.7$ \\
\hline 12 & 59 & $142.0 \pm 8.5$ & $34.2 \pm 8.8$ & $16.7 \pm 2.7$ & 45 & $141.6 \pm 8.8^{d}$ & $35.5 \pm 8.0^{d}$ & $17.5 \pm 5.5^{c}$ \\
\hline 13 & 80 & $147.8 \pm 9.5$ & $37.0 \pm 8.5^{\mathrm{a}, \mathrm{c}}$ & $16.7 \pm 2.4^{\mathrm{b}, \mathrm{d}}$ & 38 & $151.3 \pm 8.5$ & $44.1 \pm 13.2$ & $19.0 \pm 4.1$ \\
\hline 14 & 88 & $157.4 \pm 7.6^{\mathrm{d}}$ & $44.9 \pm 8.8^{d}$ & $18.0 \pm 2.4^{b}$ & 22 & $155.2 \pm 7.1$ & $48.3 \pm 12.4$ & $19.9 \pm 4.4$ \\
\hline 15 & 51 & $159.0 \pm 15.8^{d}$ & $44.8 \pm 7.4$ & $17.6 \pm 2.0^{\circ}$ & 13 & $163.2 \pm 5.0^{d}$ & $49.4 \pm 8.2$ & $18.5 \pm 2.8^{c}$ \\
\hline \multicolumn{9}{|l|}{ Girls } \\
\hline 7 & 44 & $117.0 \pm 5.2$ & $20.0 \pm 3.0$ & $14.6 \pm 1.7$ & 66 & $116.1 \pm 5.3$ & $20.6 \pm 4.3$ & $15.2 \pm 2.2$ \\
\hline 8 & 57 & $121.0 \pm 6.1$ & $21.8 \pm 5.7$ & $14.7 \pm 2.8^{\mathrm{a}}$ & 57 & $120.8 \pm 5.8$ & $23.2 \pm 5.1$ & $15.8 \pm 2.5$ \\
\hline 9 & 63 & $126.8 \pm 6.9$ & $24.6 \pm 5.8^{\mathrm{a}}$ & $15.2 \pm 2.5^{b}$ & 68 & $126.8 \pm 6.8$ & $26.9 \pm 6.9$ & $16.5 \pm 3.2$ \\
\hline 10 & 59 & $130.5 \pm 6.1^{\mathrm{a}}$ & $25.2 \pm 4.9^{b}$ & $14.8 \pm 2.3^{b}$ & 48 & $134.1 \pm 8.9$ & $32.1 \pm 9.0$ & $17.6 \pm 3.3$ \\
\hline 11 & 48 & $139.4 \pm 8.5$ & $32.8 \pm 8.6$ & $16.6 \pm 2.9$ & 65 & $137.8 \pm 7.4$ & $33.2 \pm 9.0$ & $17.2 \pm 3.5$ \\
\hline 12 & 76 & $144.8 \pm 7.7^{\mathrm{a}}$ & $36.4 \pm 8.6^{b}$ & $17.2 \pm 2.7^{b}$ & 52 & $147.7 \pm 7.1$ & $41.7 \pm 11.2$ & $18.9 \pm 3.9$ \\
\hline 13 & 101 & $148.8 \pm 6.1$ & $40.1 \pm 7.1$ & $18.0 \pm 2.6^{\mathrm{a}}$ & 35 & $147.8 \pm 9.2$ & $43.8 \pm 13.7$ & $19.6 \pm 4.9$ \\
\hline 14 & 99 & $151.3 \pm 5.1^{\mathrm{a}}$ & $41.8 \pm 7.3^{\mathrm{b}}$ & $18.2 \pm 2.7^{b}$ & 23 & $154.2 \pm 3.1$ & $48.7 \pm 8.9$ & $20.5 \pm 3.6$ \\
\hline 15 & 58 & $151.2 \pm 5.7^{\mathrm{a}}$ & $42.7 \pm 6.0^{\mathrm{b}}$ & $18.7 \pm 2.2^{b}$ & 14 & $154.9 \pm 4.5$ & $51.2 \pm 8.0$ & $21.3 \pm 3.1$ \\
\hline
\end{tabular}

between sex in the same period.

Table 2: Comparative differences in somatotypes components between boys of 1999, 2005, and 2019 from Yogyakarta Indonesia

\begin{tabular}{|c|c|c|c|c|c|c|c|c|}
\hline \multirow[t]{2}{*}{ Age } & \multicolumn{4}{|c|}{1999} & \multicolumn{4}{|c|}{2019} \\
\hline & $\mathrm{n}$ & Endomorphy & Mesomorphy & Ectomorphy & $n$ & Endomorphy & Mesomorphy & Ectomorphy \\
\hline \multicolumn{9}{|l|}{ Boys } \\
\hline 7 & 58 & $3.5 \pm 1.2$ & $4.2 \pm 1.0$ & $3.1 \pm 1.2$ & 69 & $3.6 \pm 1.4$ & $4.6 \pm 1.3$ & $2.7 \pm 1.3$ \\
\hline 8 & 47 & $3.2 \pm 1.3$ & $4.1 \pm 1.3$ & $3.4 \pm 1.4^{b}$ & 58 & $3.2 \pm 1.1^{\mathrm{d}}$ & $4.4 \pm 1.0$ & $2.7 \pm 1.1$ \\
\hline 9 & 55 & $3.5 \pm 1.3$ & $4.1 \pm 0.9^{\mathrm{b}, \mathrm{c}}$ & $3.4 \pm 1.3^{b}$ & 72 & $3.7 \pm 1.7$ & $4.8 \pm 1.6^{d}$ & $2.7 \pm 1.6$ \\
\hline 10 & 57 & $3.6 \pm 1.3$ & $4.0 \pm 1.0^{\mathrm{b}, \mathrm{d}}$ & $3.4 \pm 1.4^{\mathrm{b}, \mathrm{c}}$ & 50 & $3.8 \pm 1.8$ & $4.7 \pm 1.7$ & $2.5 \pm 1.5$ \\
\hline 11 & 57 & $3.6 \pm 1.4$ & $3.5 \pm 1.2^{\mathrm{b}}$ & $3.5 \pm 1.4^{\mathrm{b}}$ & 69 & $3.7 \pm 1.8$ & $4.5 \pm 1.4^{d}$ & $2.8 \pm 1.4$ \\
\hline 12 & 59 & $3.4 \pm 1.3^{\mathrm{c}}$ & $3.2 \pm 1.2^{\mathrm{b}, \mathrm{d}}$ & $3.7 \pm 1.4^{\mathrm{a}}$ & 45 & $3.1 \pm 1.3^{\mathrm{d}}$ & $4.4 \pm 1.1$ & $3.2 \pm 1.3$ \\
\hline 13 & 80 & $3.2 \pm 1.3^{\mathrm{d}}$ & $2.5 \pm 1.1^{\mathrm{b}, \mathrm{c}}$ & $4.1 \pm 1.3^{\mathrm{b}, \mathrm{d}}$ & 38 & $3.6 \pm 1.6^{c}$ & $4.3 \pm 1.4$ & $3.2 \pm 1.6$ \\
\hline 14 & 88 & $3.2 \pm 1.2^{\mathrm{a}, \mathrm{d}}$ & $2.4 \pm 1.3^{\mathrm{b}, \mathrm{c}}$ & $4.0 \pm 1.3^{\mathrm{b}, \mathrm{c}}$ & 22 & $3.9 \pm 1.9 d$ & $4.5 \pm 1.8$ & $3.1 \pm 1.8$ \\
\hline 15 & 51 & $2.8 \pm 1.0^{d}$ & $2.0 \pm 1.0^{\mathrm{b}}$ & $4.3 \pm 1.2^{\mathrm{d}}$ & 13 & $3.0 \pm 1.1^{\mathrm{d}}$ & $3.5 \pm 1.0^{c}$ & $4.1 \pm 1.6^{d}$ \\
\hline \multicolumn{9}{|l|}{ Girls } \\
\hline 7 & 44 & $3.5 \pm 0.9$ & $4.0 \pm 0.9$ & $3.1 \pm 2.1$ & 66 & $3.8 \pm 1.3$ & $4.3 \pm 0.9$ & $2.6 \pm 1.3$ \\
\hline 8 & 57 & $3.5 \pm 1.3$ & $3.8 \pm 1.2^{\mathrm{a}}$ & $3.5 \pm 1.4^{\mathrm{b}}$ & 57 & $3.8 \pm 1.3$ & $4.2 \pm 1.1$ & $2.7 \pm 1.1$ \\
\hline 9 & 63 & $3.7 \pm 1.3$ & $3.6 \pm 1.1^{\mathrm{a}}$ & $3.6 \pm 1.5^{b}$ & 68 & $4.0 \pm 1.6$ & $4.1 \pm 1.3$ & $2.8 \pm 1.4$ \\
\hline 10 & 59 & $3.5 \pm 1.2^{b}$ & $3.2 \pm 0.9^{b}$ & $4.2 \pm 2.0^{\mathrm{b}}$ & 48 & $4.2 \pm 1.6$ & $4.3 \pm 1.5$ & $2.7 \pm 1.4$ \\
\hline 11 & 48 & $3.7 \pm 1.4$ & $3.3 \pm 1.0^{\mathrm{a}}$ & $3.6 \pm 1.5$ & 65 & $4.0 \pm 1.6$ & $3.9 \pm 1.4$ & $3.3 \pm 1.6$ \\
\hline 12 & 76 & $4.0 \pm 1.2$ & $2.5 \pm 0.9^{b}$ & $3.7 \pm 1.4^{\mathrm{b}}$ & 52 & $4.3 \pm 1.5$ & $3.9 \pm 1.4$ & $3.1 \pm 1.7$ \\
\hline 13 & 101 & $4.3 \pm 1.3$ & $2.1 \pm 1.0^{\mathrm{b}}$ & $3.5 \pm 1.3$ & 35 & $4.6 \pm 1.7$ & $4.0 \pm 1.8$ & $2.9 \pm 1.9$ \\
\hline 14 & 99 & $4.5 \pm 1.2$ & $2.0 \pm 1.0^{b}$ & $3.5 \pm 1.4^{\mathrm{a}}$ & 23 & $5.0 \pm 1.7$ & $3.9 \pm 1.4$ & $2.6 \pm 1.6$ \\
\hline 15 & 58 & $4.5 \pm 1.3$ & $2.2 \pm 1.0^{\mathrm{b}}$ & $3.2 \pm 1.3^{\mathrm{a}}$ & 14 & $4.7 \pm 1.4$ & $4.3 \pm 1.3$ & $2.2 \pm 1.4$ \\
\hline
\end{tabular}

p $<0.05$ d erences between periods (1999 and 2019) within the same sex; ${ }^{b} p<0.01$ differences between periods (1999 and 2019) within the same sex; ${ }^{\circ} p<0.05$ differences between sex in the same period;

$p<0.01$ differences between sex in the same period. 


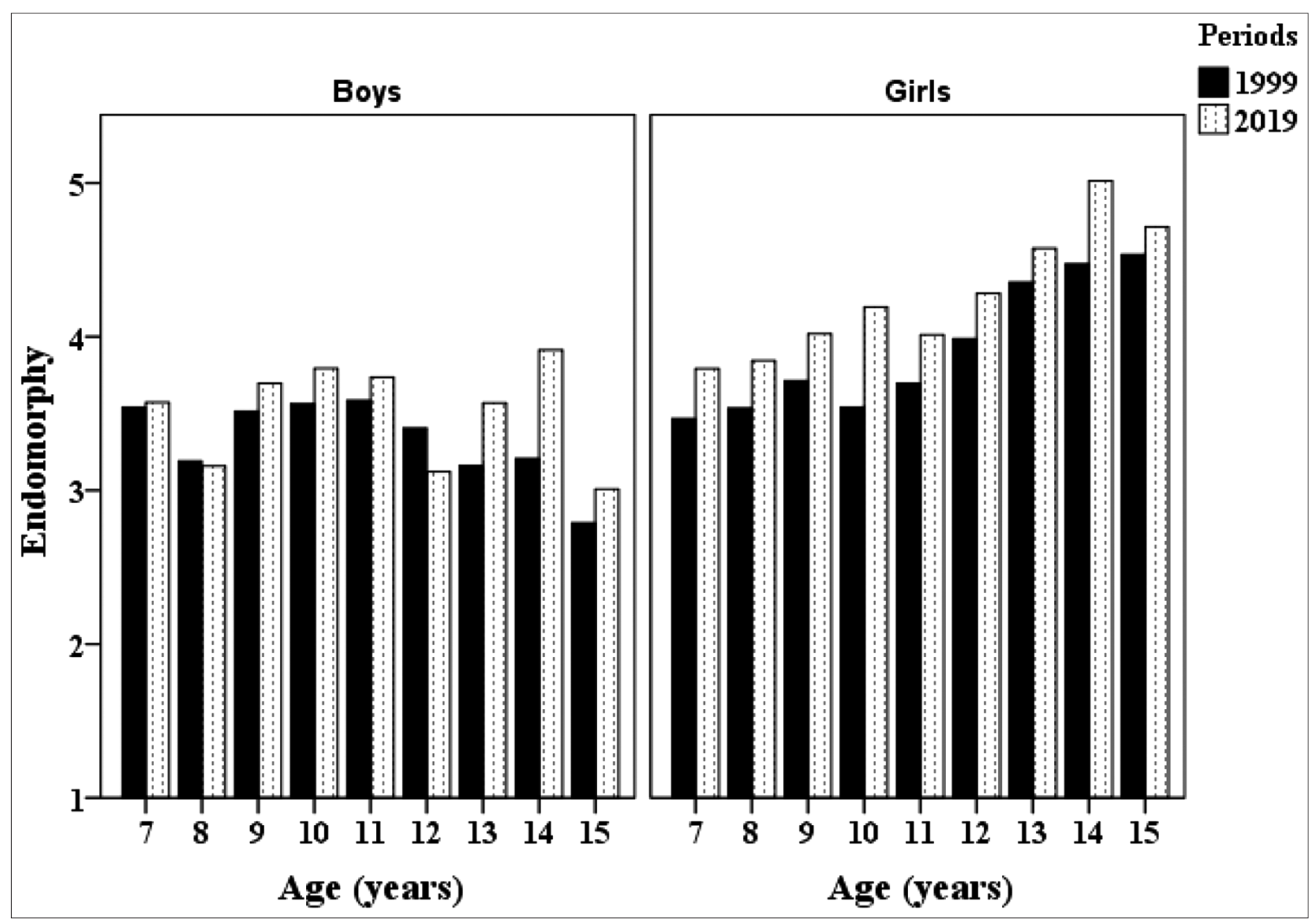

Figure 1: Means of endomorphy component of boys and girls aged 7-15 years old between 1999 and 2019; significant differences in boys at 14 years $(p<0.05)$, while girls at 10 years $(p<0.01)$

Patterns of endomorph component of boys and girls in 1999 and 2019 are displayed in Figure 1. Endomorph component in boys between 1999 and 2019 showed a positive secular trend only at 14 years (0.7 units) and in girls at 10 years (0.7 units). The values of the components may differ; however, the patterns of the changes were similar between boys and girls in the two periods. Most girls significantly had a greater endomorph component than boys at 12 years and above both in 1999 and 2019 (Table 2).

Mesomorph component was almost similar between boys and girls in 1999 and 2019 (Figure 2). Positive secular trends $(0.05>p<0.01)$ in mesomorph component between 1999 and 2019 were observed at $9-15$ years in boys with the largest increase at 13 years (1.9 units) and in girls from 8 years upward with the highest increment at 15 years (2.1 units). The means of mesomorph component in boys ranged from 2.0 to 4.2 (1999) and 3.5 to 4.8 (2019), while in girls from 2.0 to 4.0 (1999) and 3.9 to 4.3 (2019). Further analyses indicated that the means of mesomorph component were greater in boys than girls, and there was a tendency to decline in all periods with the increasing ages except for girls aged 15 years (Table 2). Results showed a significant increase in the mesomorph component over the 20 years interval, with the greatest increase at 14 years (2.1 unit) for boys and for girls at 15 years (2.1 unit).

Figure 3 describes patterns of ectomorph component in boys and girls. There was a downward trend in ectomorph component over 20 years. Between 1999 and 2019, there were significant differences $(p<0.01)$ in boys from 8 to 14 years, with the largest decrease of -0.9 unit. Meanwhile, in girls, differences $(p<0.01)$ existed from aged 8 to 15 years, except for 11 and 13 years, with the largest decrease of -1.5 units. Significant differences $(p<0.01)$ in ectomorph component were also found between both sexes in 1999 at ages 10, 13-15 years and at 15 years in 2019 (Table 2). The results showed a negative secular trend in the value of the ectomorph component over a 20 years period with a mean decrease of about -0.7 -0.8 units in both boys and girls.

\section{Discussion}

A 20-year-long assessment of the body size, $\mathrm{BMI}$, and somatotype of Yogyakarta children showed that from 1999 to 2019, the height of boys showed no 


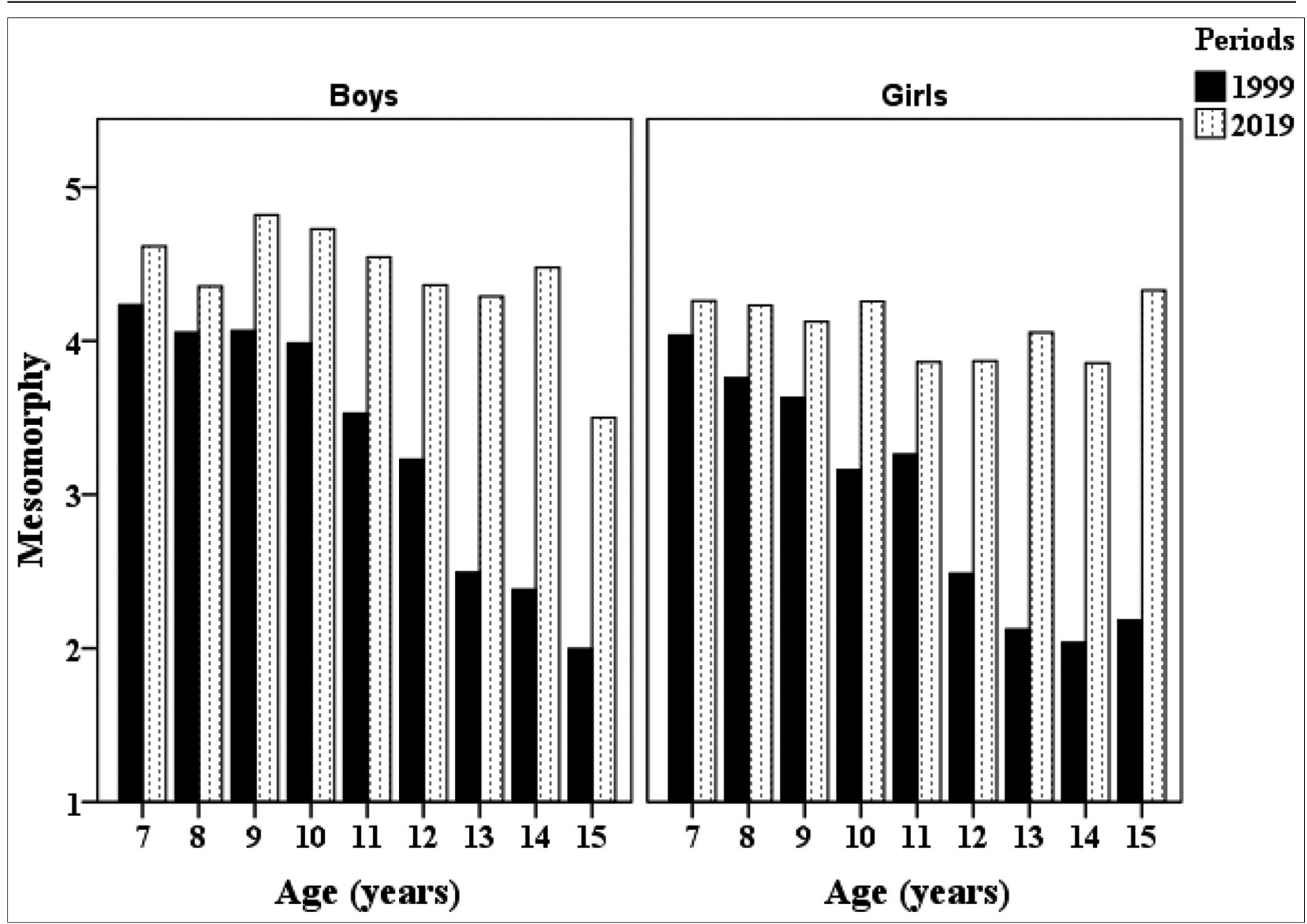

Figure 2: Means of mesomorphy component of boys and girls aged 7-15 years old between 1999 and 2019; significant differences in boys at 9 and 15 years $(p<0.01)$, while girls at 8 and 15 years $(0.05>p<0.01)$

significant difference; however, there were significant and positive differences among girls aged 10, 12, 14, and 15 years. It demonstrated that the secular trend of height varied with age and sex. Cole [18] indicated that secular trends in height vary with age; it is usually the same after puberty, but it becomes faster or slower at the onset of age. One study conducted by Fu et al. [11] showed that there are positive secular trends in height which is higher during the onset of puberty and then dramatically decreased during the middle and end of puberty (after age 12 years). A number of studies have also analyzed the trends in height at certain ages [8], [11], [12], [19], [20], [21], [22]. Compared with boys and girls of our study in the same age indicated a lower average height of our samples than those of previous studies, as well as when compared to Turkish children aged 6-17 years [23] and Italian children aged 9-10 years [24].

Along with secular changes in height, there are also changes in body weight, both in boys and girls. The average body weight of children in Yogyakarta between 1999 and 2019 aged 7 and 15 years (Table 1) ranged from 21.1 to $49.4 \mathrm{~kg}$ (boys) and 20.0 to $51.2 \mathrm{~kg}$ (girls). Those values were lower than children in Beijing [22] from 1995 to 2010 , that is, ranged from 24.2 to $66.7 \mathrm{~kg}$ (boys) and 23.6 to $54.6 \mathrm{~kg}$ (girls). Children of our samples at aged 7 years (21.6 kg in boys and $20.3 \mathrm{~kg}$ in girls) also were lighter than children in Serbia of the same age during 2005-2014 [20], that is, 24.21 and $22.9 \mathrm{~kg}$ for boys and girls, respectively. Compared with the results of a study in Chile [12], children aged 7-9 years in Yogyakarta had less body weight in the same ages, as well as when compared with children aged 8-15 years in Zambia, Zimbabwe between the periods of 1982, 1999, and 2012 [8]. These differences are likely due to genetic, race, and environmental factors, including stagnation in living standards and socio-economic conditions that affect secular trends in height and consequently the BMI [21], [22], [25], [26], [27].

A positive secular trend in weight was found in children in Yogyakarta between 1999 and 2019, probably due to reduced physical activities among girls which were significantly noticeable at the age of 12 years and among boys 1 year after. Indonesia Basic Health Research [28] indicated that there was an estimated $26.1 \%$ decrease in physical activities and $24.1 \%$ of adolescents in Indonesia had a sedentary lifestyle with an average of 6 h/day. Hallal et al. [29] also found that out of 122 countries, the prevalence of less physical activity for children aged 15 years and above was $31.1 \%$. Reducing physical activity will increase the risk of non-communicable diseases, and in developing 


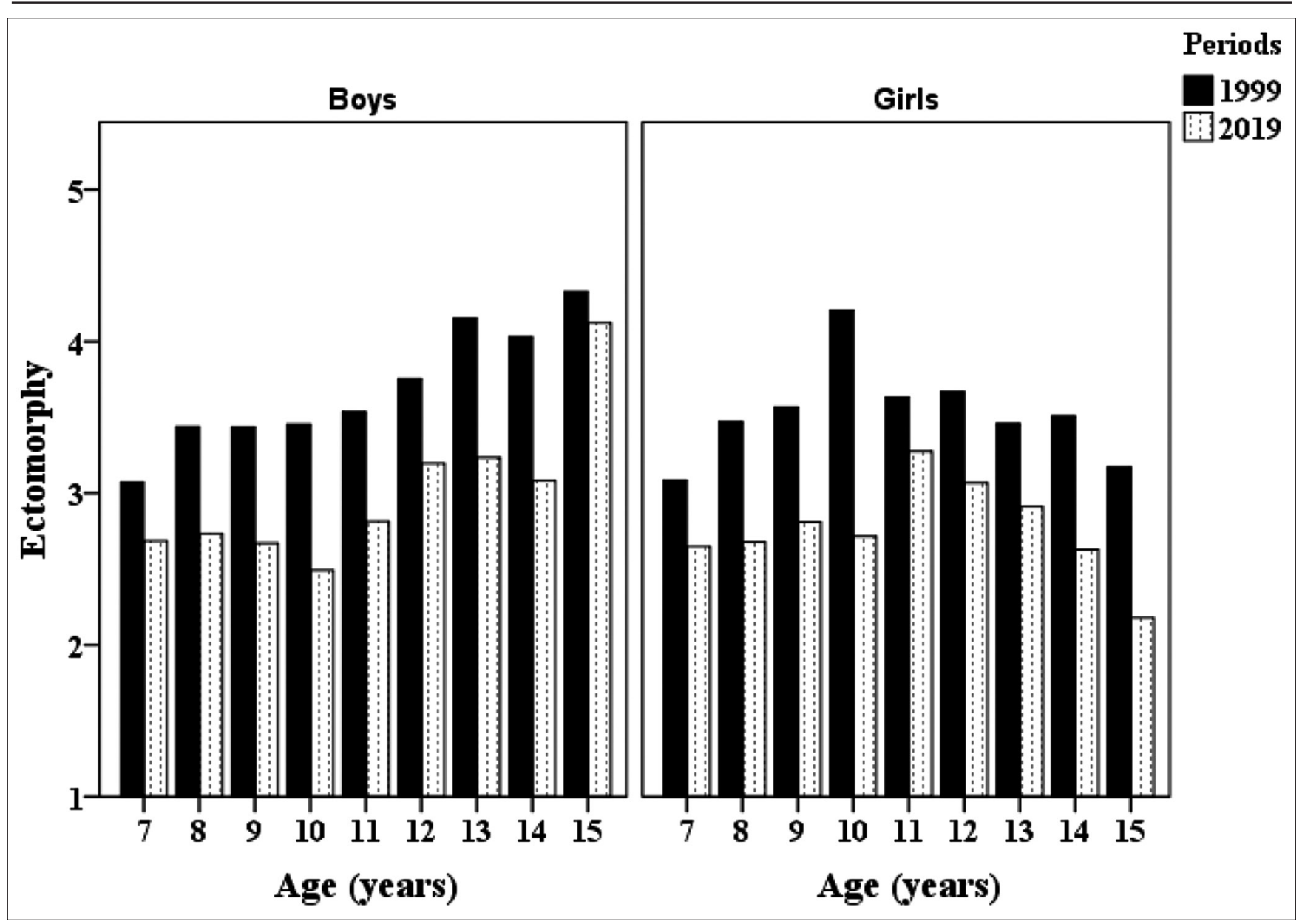

Figure 3: Means of ectomorphy component of boys and girls aged 7-15 years old between 1999 and 2019; significant differences in boys at 8 and 14 years $(0.05>p<0.01)$, while girls at $8-15$ years $(0.05>p<0.01)$, except at 11 and 13 years

countries such as Indonesia, this fact will lead to serious problems because there will be extra expenses to deal with both infectious and non-communicable diseases, according to the World Health Organization [30].

The trend in height is a positive phenomenon, but the trend in weight is not. Body weight is characterized by greater changes. Yet, it is less genetically determined than height because body mass can change more rapidly, being especially affected by changes in lifestyle, physical activities, nutrition, and diseases [31]. The variability of the average weight in our study had different patterns compared to height. Body weight indicated significant differences at large intervals. Both height and weight regardless of sexes in the same period showed significant differences at puberty, that is, at 13-15 years in 1999 and at 12 and 15 years in 2019. This consequently affects the changes in the BMI which showed a positive secular trend in almost all age groups between 1999 and 2019 and the value was greater in girls than boys at puberty (Table 1). A similar trend was found in a study [8] among students in Poland in a 49-year interval, showing a positive secular trend in BMI $\left(0.7 \mathrm{~kg} / \mathrm{m}^{2}\right.$ increase).

Analysis of the somatotype components showed that a secular trend in Yogyakarta children over 20 years was also observed. There was a change in somatotype between 1999 and 2019 from ideal type to endo-mesomorph in boys and from ectomorphic endomorph to mesomorphic endomorph in girls (Table 2). An increased mesomorph component (1.2 units) in boys and a decreased ectomorph in girls (by 1.1 units) was also observed, while the changes in endomorphy were not as much as the other two components in both boys and girls. It is obvious that the decrease of ectomorph component was greater in girls, which is in line with the secular trend in height in girls (Table 1), while a higher mesomorph component existed in boys. Accordingly, there was a positive secular trend in the mesomorphy and endomorphy values but a negative secular trend in the ectomorphy value. These results were not consistent with a study in Polish students (1967-2008) where a negative secular trend in endomorphy and a positive secular trend in ectomorph components were observed [32]. Body weight in the somatotype assessment is directly proportional to endomorphy and inversely proportional to ectomorphy, as presented in Table 1 and Figures 1 and 3 . It is obvious that the increased body weight in 2019 confirms a reduction in the ectomorphic value and an increase in the value of the endomorphic significantly.

Our study also found an increase in the endomorph component of children between 1999 and 
2019 at 14 years boys and 10,12-14 years girls. In addition, our findings demonstrate the presence of sexual dimorphism, in which girls tend to have more adipose tissues and consequently a greater endomorphic value. On the other hand, boys have a greater mesomorph (musculoskeletal) component, and this may indicate a change in body composition in both sexes over the years [33]. These results support a study on children and adolescents in Chile aged 6-18 years from 2009 to 2010 [18].

Mesomorph, which represents musculoskeletal robustness, plays a critical role in somatotype in both boys and girls, in which boys have a greater value than girls. On the other hand, girls have a greater value of endomorph component, with sexual dimorphism in body shape and composition resulting from differences in hormonal profiles between the sexes [32]. In boys, sex hormones, namely testosterone, will increase the metabolic rate by about $10-15 \%$, while in girls, sex hormone may cause an insignificant increase in the basal metabolic rate. The most significant effect of the sex hormones in boys is related to anabolic effects to strengthen skeletal muscle mass [34], while in girls, the estrogen promotes the accumulation of subcutaneous fat. In addition, the mesomorph component is also closely related to height [35], which is in line with our results that boys are significantly taller than girls at puberty (Table 1).

In terms of ectomorph component, Figure 3 displays a negative secular ectomorph trend between 1999 and 2019, with the same pattern according to sex and different patterns between sexes. This study shows an increasing trend of body weight and decreasing value of ectomorphic components among both sexes. Both boys and girls in our study had ectomorph values in the low-moderate category $(1,3$, and 4.1$)$, with a decrease in the average ectomorph value of -0.75 units from 1999 to 2019. These results confirmed a study among children in Chile from 1983 to 2011 [32], which also showed negative secular trends in the ectomorph component. In addition, both boys and girls had almost the same ectomorph value and there was no sexual dimorphism in the ectomorph component, but after puberty, sexual dimorphism started to emerge at 15 years (2019) and 13 years (1999). Overall, somatotype analysis in a 20-year interval showed that children in 2019 were more endomorphic and mesomorphic but less ectomorphic if compared with their peers in 1999 (Figures 1-3), indicating that children in Yogyakarta in 2019 tended to be more muscular with stronger muscle development.

Analysis over a period of 20 years showed that body weight has a greater influence on changes in BMI compared to height in both boys and girls. This pattern is indicated by our findings that showed changes in height only occurred in girls, which also affected the somatotype component, especially the mesomorphic and ectomorphic components. This study has several limitations, such as socioeconomic factors, diet, physical activity, and environmental factors that have not been investigated, which are actually very influential. Nevertheless, the results point to the need of further studies of children living in different regions of Indonesia to provide better insights into changes in morphological parameters associated with their environment. In addition, it is important to perform laboratory tests as blood analysis to evaluate the changes in health status.

\section{Conclusion}

In summary, this study showed that during the period 1999-2019, (1) there were significant and positive secular trends in height, weight, and BMI among children in Yogyakarta in a 20-year interval, (2) the positive trend of the somatotype component was found in the mesomorph component, while the ectomorph component showed a negative trend. On the one side, we see the improvement of nutritional status in Yogyakarta children, but on the other side, there are probably some increases in the prevalence of overweight and obesity. These data are particularly important for policymakers in local public health for the prevention of risk factors for disease due to the increasing incidence of obesity in children. Therefore, with the results of this study, we recommend encouraging an active lifestyle by increasing physical activity and a healthy diet should be considered as a public health priority.

\section{Acknowledgments}

We appreciate the students, directors, and teachers of schools in Yogyakarta Province, Indonesia, for their cooperation in this research. This research was supported by Faculty of Medicine, Public Health and Nursing, Universitas Gadjah Mada, Yogyakarta, Indonesia.

\section{References}

1. Cole TJ. The secular trend in human physical growth: A biological view. Econ Hum Biol. 2003;1(2):161-8. PMid:15463971

2. Papadimitriou A, Fytanidis G, Douros K, Papadimitriou DT, Nicolaidou P, Fretzayas A. Greek young men grow taller. Acta Paediatr. 2008;97(8):1105-7. https://doi. org/10.1111/j.1651-2227.2008.00855.x

PMid:18477057 
3. Conde WL, Rinaldi AE, Enes CC. Is the secular trend in height delaying overweight rise among adolescents? The Brazilian case. Public Health Nutr. 2016;19(12):2213-9. https://doi. org/10.1017/s1368980016000203

PMid:26888210

4. Jacobsen BK, Melhus M, Kvaløy K, Siri SR, Michalsen VL, Broderstad AR. A descriptive study of ten-year longitudinal changes in weight and waist circumference in the multi-ethnic rural Northern Norway. The SAMINOR Study, 2003-2014. PLoS One. 2020;15(2):e0229234. https://doi.org/10.1371/journal. pone.0229234

PMid:32074126

5. Orden AB, Bucci PJ, Petrone S. Trends in weight, height, BMI and obesity in schoolchildren from Santa Rosa (Argentina), 1990-2005/07. Ann Hum Biol. 2013;40(4):348-54. https://doi. org/10.3109/03014460.2013.778329

PMid:23590702

6. Song Y, Wang HJ, Ma J, Wang Z. Secular trends of obesity prevalence in urban Chinese children from 1985 to 2010: Gender disparity. PLoS ONE. 2013;8(1):e53069. https://doi. org/10.1371/journal.pone.0053069

PMid:23308137

7. Parrino C, Rossetti P, Baratta R, La Spina N, La Delfa L, Squatrito $\mathrm{S}$, et al. Secular trends in the prevalence of overweight and obesity in sicilian schoolchildren aged 11-13 years during the last decade. PLoS One. 2012;7(4):e34551. https://doi. org/10.1371/journal.pone. 0034551

PMid:22506027

8. Dos Santos FK, Maia JA, Gomes TN, Daca T, Madeira A, Katzmarzyk PT, et al. Secular trends in growth and nutritional status of Mozambican school-aged children and adolescents. PLoS One. 2014;9(12):e114068. https://doi.org/10.1371/journal. pone. 0114068

PMid:25473837

9. Albataineh SR, Badran EF, Tayyem RF. Overweight and obesity in childhood: Dietery, biochemical, inflammatory and lifestyle risk factors. Obes Med. 2019;15:100112. https://doi.org/10.1016/j. obmed.2019.100112

10. Kryst $\measuredangle$, Kowal M, Woronkowicz A, Sobiecki J, Cichocka B. Secular changes in height, body weight, body mass index and pubertal development in male children and adolescents in Krakow, Poland. J Biosoc Sci. 2012;44(4):495-507. https://doi. org/10.1017/s0021932011000721

PMid:22225553

11. Fu LG, Sun LL, Wu SW, Yang $\mathrm{Y}$, Li XH, Wang ZH, et al. The influence of secular trends in body height and weight on the prevalence of overweight and obesity among Chinese children and adolescents. Biomed Environ Sci. 2016;29(12):849-57. PMid:28081745

12. Lizana PA, Simpson MC, Farías P, Berral FJ. Somatotypes of schoolchildren from Chile: Higher endomorphic components among adolescent girls. Nutr Hosp. 2018;35(5):1033-41. https:// doi.org/10.20960/nh.1749 PMid:30307283

13. Carter JE, Heath BH. Somatotyping, Development and Applications. Cambridge: Cambridge University Press; 1990.

14. Lizana PA, Olivares R, Berral FJ. Somatotype tendency in Chilean adolescents from Valparaíso: Review from 1979 to 2011. Nutr Hosp. 2014;31(3):1034-43.

PMid:25726190

15. Lizana PA, González S, Lera L, Leyton B. Association between body composition, somatotype and socioeconomic status in Chilean children and adolescents at different school levels. J Biosoc Sci. 2018;50(1):53-69. https://doi.org/10.1017/ s0021932017000025

\section{PMid:28238292}

16. Rahmawati NT, Hastuti J, Ashizawa K. Growth and somatotype of urban and rural Javanese children in Yogyakarta and Bantul, Indonesia. Anthropol Sci. 2004;112:99-108. https://doi. org/10.1537/ase.00074

17. Marfell-Jones M, Olds T, Stewart A, Carter L. International Standards for Anthropometric Assessment. Lower Hutt: International Society for the Advancement of Kinanthropometry; 2006.

18. Cole TJ. Secular trend in growth. Proc Nutr Soc. 2000;59(2):317-24.

PMid:10946801

19. Pavlica T, Rakic R, Sironjic T. Changes in morphological characteristics during the period 2005-2014 in a sample of Serbian 7-year-old children. Int J Morphol. 2017;35(2):691-7. https://doi.org/10.4067/s0717-95022017000200049

20. Fudvoye J, Parent AS. Secular trends in growth. Ann Endocrinol. 2017;78(2):88-91.

PMid:28483361

21. Pavlica TM, Rakić RS, Popović BK, Puškaš PV. Secular trend in growth and nutritional status in sample of girls aged 7-9 from Serbia. Homo. 2018;69(5):280-6. https://doi.org/10.1016/j. jchb.2018.09.002

PMid:30269925

22. Lu R, Zeng X, Duan J, Gao T, Huo D, Zhou T, et al. Secular growth trends among children in Beijing (1955-2010). Econ Hum Biol. 2016;21:210-20. https://doi.org/10.1016/j.ehb.2015.08.009 PMid:26975006

23. Bundak R, Bas F, Furman A, Günöz H, Darendeliler F, Saka N, et al. Sitting height and sitting height/height ratio references for Turkish children. Eur J Pediatr. 2014;173(7):861-9. https://doi. org/10.1007/s00431-013-2212-3 PMid:24401935

24. De Miranda RD, Di Renzo L, Cupertino V, Romano L, De Lorenzo A, Salimei C, et al. Secular trend of childhood nutritional status in Calabria (Italy) and the United States: The spread of obesity. Nutr Res. 2019;62:23-31. https://doi.org/10.1016/j. nutres.2018.10.008

25. Zhang YY, Liu PY, Lu Y, Davies KM, Dvornyk V, Recker RR, et al. Race and sex differences and contribution of height: A study on bone size in healthy Caucasians and Chinese. Am J Hum Biol. 2005;7(5):568-75. https://doi.org/10.1016/j.nutres.2018.10.008 PMid: 16136538

26. Dubois L, Kyvik KO, Girard M, Tatone-Tokuda F, Pérusse D, Hjelmborg J, et al. Genetic and environmental contributions to weight, height, and BMI from birth to 19 years of age: An international study of over 12,000 twin pairs. PLoS One. 2012;7(2):e30153. https://doi.org/10.1371/journal. pone. 0030153

PMid:22347368

27. Graham EA. Economic, racial and cultural influences on the growth and maturation on children. Pediatr Rev. 2005;26(8):290-4.

PMid: 16061527

28. The Indonesian Basic Health Research. Health Research and Development Agency of the Ministry of Health of the Republic of Indonesia. Jakarta: The Indonesian Basic Health Research; 2018. https://doi.org/10.17501/24246735.2018.4105

29. Hallal PC, Andrese LB, Bull LC, Guthold R, Haskell W, Ekelund U. Global physical activity levels: Surveillance progress, pitfalls, and prospect. Lancet. 2012;380(9838):247-57. https:// doi.org/10.1016/s0140-6736(12)60646-1 PMid:22818937

30. World Health Organization. Obesity and Overweight. Geneva: World Health Organization; 2018. Available from: https://www. 
who.int/news-room/fact-sheets/detail/obesity-and-overweight. [Last accessed on 2019 Aug 18]. https://doi.org/10.1787/ a47d0cd2-en

31. Podstawski RS, Borysławski K. Secular trends in height, weight and BMI of students at the University of Warmia and Mazury in 2000-2006 years depending on their place of residence and type of completed secondary school. Zeszyty Naukowe Uniwersytetu Przyrodniczego we Wrocławiu. Biol Anim Breed. 2012;14(586):9-18.

32. Stachon A, Burdukiewicz A, Pietraszewska J, Andrzejewska J. Changes in body build of AWF students 1967-2008: Can a secular trend be observed? Hum Mov. 2012;13(2):109-19. https://doi.org/10.2478/v10038-012-0011-8

33. Malina RM, Bouchard C, Bar-Or O. Growth, Maturation, and Physical Activity. Champaign: Human Kinetics Books Champaign; 2004.

34. Guyton AC, Hall JE. Textbook of Medical Physiology Philadelphia, PA: Elsevier Inc.; 2016.

35. Gakhar I, Malik SI. Age changes and sex differences in somatotypes among Jats of Delhi. Anthropologist. 2002;1:11525. https://doi.org/10.1080/09720073.2002.11890737 